\title{
PENGARUH PENDIDIKAN KESEHATAN TENTANG KESIAPSIAGAAN MASYARAKAT TERHADAP SIKAP MASYARAKAT DALAM MENGATASI MASALAH KESEHATAN AKIBAT BENCANA TANAH LONGSOR
}

\author{
Evi Tunjung Fitriani ${ }^{1}$, Febriana In Patmiati $^{1}$ \\ ${ }^{1}$ STIKes Hutama Abdi Husada Tulungagung \\ evitunjungfitriani@gmail.com
}

\begin{abstract}
ABSTRAK
Pendididikan kesehatan tentang kesiapsiagaan, mampu mempersiapkan masyarakat untuk mengantisipasi masalah kesehatan yang mungkin terjadi. Tujuan penelitian untuk mengetahui adanya pengaruh pendidikan kesehatan tentang kesiapsiagaan masyarakat terhadap sikap masyarakat dalam mengatasi masalah kesehatan akibat bencana tanah longsor. Desain yang digunakan dalam penelitian ini adalah pre eksperimen dengan rancangan pre test post test. Populasi penelitian ini adalah anggota keluarga di Desa Nglurup yang berjumlah 162 kepala keluarga, dengan sampel sejumlah 40 responden yang diambil dengan teknik quota Sampling. Pengambilan data dengan menggunakan lembar kuisioner. Selanjutnya dianalisa dengan uji statistic Wilcoxon Signed Rank Test. Hasil penelitian didapatkan sejumlah $67,5 \%$ responden memiliki sikap positif terhadap kesiapsiagaan masyarakat sebelum diberikan pendidikan kesehatan. Setelah diberikan pendidikan kesehatan sejumlah $75 \%$ masyarakat mempunyai sikap positif. Berdasarkan uji statistic Wilcoxon diperoleh nilai $\mathrm{p}=0.001$ ( $\mathrm{p}$ value <0.05) sehingga $\mathrm{H}_{0}$ ditolak yang artinya ada pengaruh pendidikan kesehatan tentang kesiapsiagaan masyarakat terhadap sikap masyarakat dalam mengatasi masalah kesehatan akibat bencana tanah longsor. Masyarakat mampu menerapkan kesiapsiagaan bencana yang telah diberikan petugas kesehatan untuk mengetahui tindakan-tindakan yang harus dilakukan pada saat terjadi bencana.
\end{abstract}

Kata kunci: Bencana, tanah longsor, kesiapsiagaan.

\section{HEALTH EDUCATION INFLUENCE ABOUT COMMUNITY PROSPERITY ON COMMUNITY ATTITUDES IN OVERCOMING HEALTH PROBLEMS CAUSED BY LAND DISASTER}

\begin{abstract}
Health education about preparedness, is able to prepare the community to anticipate possible health problems. The research objective was to determine the effect of health education about community preparedness on people's attitudes in overcoming health problems due to landslides. The design used in this study was pre-experiment with the design of the pre-test post test. The population of this study was family members in Nglurup Village, which amounted to 162 families, with a sample of 40 respondents taken by quota sampling technique. Retrieving data using questionnaire sheets. Then analyzed by the Wilcoxon Signed Rank Test statistical test. The results of the study found $67.5 \%$ of respondents had a positive attitude towards community preparedness before being given health education. After being given health education, $75 \%$ of the people have a positive attitude. Based on the Wilcoxon statistical test, the value of $p=0.001$ ( $p$ value $<0.05$ ) is obtained so that HO is rejected, which means that there is an influence of health education about community preparedness towards people's attitudes in overcoming health problems due to landslides. The community is able to implement disaster preparedness that has been given by health workers to know the actions that must be taken in the event of a disaster.
\end{abstract}

Keywords: Disasters, landslides, preparedness.

\section{PENDAHULUAN}

Secara geografis Indonesia merupakan negara kepulauan yang terletak pada pertemuan empat lempeng tektonik yaitu lempeng Benua Asia, Benua Australia, lempeng Samudra Hindia dan Samudra Pasifik. Pada bagian selatan dan 
timur Indonesia terdapat sabuk vulkanik (vulcanic arc) yang memanjang dari Pulau Sumatra-Jawa-Nusa Tenggara- Sulawesi, yang sisinya berupa pegunungan vulkanik tua dan daratan rendah yang sebagian didominasi oleh rawa-rawa. Kondisi tersebut sangat berpotensi sekaligus rawan bencana seperti letusan gunung merapi, gempa bumi, tsunami, banjir dan tanah longsor (Wiarto, 2017).

Menurut Ramli (2010) faktor-faktor kerentanan Indonesia terhadap bencana antara lain faktor geografis, faktor geologi, dan faktor hidrometeorologi. Pengaruh iklim, badai tropis, dan arus laut serta adanya pantai-pantai yang memanjang disepanjang samudera menjadikan daerah Indonesia rawan terhadap bahaya gelombang pasang dan tsunami. Dari sisi geologi Indonesia tempat bertemunya empat lempeng yang masing-masing mempunyai gerakan sendiri dengan arah berbeda dan saling bergeser. Kondisi ini mengakibatkan penumpukan energi yang jika tidak bisa ditahan lagi akan menimbulkan gempa. Selain itu, dari faktor hidrometeorologi, Indonesia terdiri atas pulaupulau yang dialiri olehsungai-sungai yang besar dan beraliran deras. Curah hujan di Indonesia sebagai suatu kawasan tropis juga tergolong tinggi sehingga menimbulkan kerawanan adanya bahaya banjir dan tanah longsor.

Tanah longsor adalah salah satu jenis gerakan massa tanah atau batuan, ataupun percampuran keduanya, menuruni atau keluar lereng akibat dari terganggunya kestabilan tanah atau batuan penyusun lereng tersebut. Tanah longsor terjadi karena ada gangguan kestabilan pada tanah/batuan penyusun lereng. Hujan deras adalah pemicu utama terjadinya tanah longsor. Faktor lain yang memengaruhi terjadinya bencana tanah longsor adalah ulah manusia, seperti penebangan liar, penambangan tanah, pasir, dan batu yang tidak terkendali. Bencana tanah longsor merupakan salah satu bencana alam geologi yang dapat menimbulkan korban jiwa dan kerugian material yang sangat besar, seperti terjadinyapendangkalan, terganggunya jalur lalu lintas, rusaknya lahan pertanian, permukiman,jembatan, saluran irigasi dan prasaranafisik lainnya (Ramli, 2010).
Berdasarkan survei BNPB menunjukkan bahwa dalam tahun 2016 sampai Bulan November terjadi 2.151 kejadian bencana. Dengan angka kejadian terbanyak adalah banjir dengan 713 kejadian diikuti oleh puting beliung dengan 608 kejadian dan tanah longsor dengan 552 kejadian. Dalam kejadian bencana tersebut mengakibatkan korban meninggal dan hilang sejumlah 567 jiwa, sedangkan korbanmenderita danmengungsisejumlah 2.771.303 jiwa, kerusakan pemukiman mencapai 36.296 unit.

Menurut Sutopo (2016) dampak yang ditimbulkan bencana selama tahun 2016 adalah 375 orang tewas, 383 jiwa luka-luka, 2,52 juta jiwa menderita dan mengungsi, dan lebih dari 34 ribu rumah rusak. Diprediksi dampak bencana ini akan terus bertambah. Bencana tanah longsor merupakan bencana yang menimbulkan korban tewas paling banyak yaitu 161 jiwa.

Menurut data dari Dinas Kesehatan Kabupaten Tulungagung, pada tahun 2015 sudah terjadi 5 (lima) kejadian bencana tanah longsor melanda Kecamatan Pagerwojo (Desa Mulyosari, Gondanggunung, Gambiran) dan Kecamatan Sendang (Desa Krosok). Tahun 2016 tercatat sebanyak 12 (dua belas) kejadian bencana tanah longsor di wilayah Kecamatan Pagerwojo (Desa Wonorejo, Mulyosari, Kradinan, Samar, Pagerwojo, Segawe), Kecamatan Sendang (Desa Nyawangan, Kedoyo), dan Kecamatan Besuki (desa Sedayugunung). Dampak yang ditimbulkan antara lain 13 rumah rusak ringan, 3 rumah rusak sedang, 2 rumah berat, akses jalan desa terganggu/terputus, rusaknya area ladang pekarangan milik warga setempat.

Dampak yang terjadi bila masyarakat tidak mengetahui Kesiapsiagaan menghadapi bencana tanah longsor adalah masyarakat tidak bisa maksimal dalam merespon secara cepat situasi bencana secara efektif dengan menggunakan kapasitas sendiri. Selain itu, juga terdapat dampak yang dialami masyarakat secara langsung yaitu berbagai masalah kesehatan pasca terjadinya bencana tanah longsor seperti penyediaan air bersih, sanitasi lingkungan juga permasalahan mengenai suplai bahan makanan dan obatobatan yang akan menimbulkan berbagai 
masalah lainnya, seperti kekurangan gizi dan penyakit infeksi atau wabah berupa infeksi pencernaan (GED), infeksi pernapasan akut seperti influensa, dan penyakit kulit. Padahal upaya penanggulangan pra bencana tanah longsor dapat dilakukan dengan cara pemberian Pendidikan Kesehatan (Penyuluhan) tentang Kesiapsiagaan bencana pada tingkat masyarakat (Aminto, 2013).

Upaya yang dilakukan dapat berupa Penyuluhan kesehatan atau bisa disebut juga pendidikan kesehatan yang diartikan sebagai proses untuk meningkatkan kemampuan masyarakat dalam memelihara dan meningkatkan kesehatan agar orang mampu menerapkan masalah dan kebutuhan mereka sendiri, mampu memahami apa yang dapat mereka lakukan terhadap masalahnya, dengan sumber daya yang ada pada mereka ditambah dengan dukungan dari luar, dan mampu memutuskan kegiatan yang tepat guna untuk meningkatkan taraf hidup sehat dan kesejahteraan masyarakat (Notoadmodjo,2013).

Oleh karena itu, penting adanya upaya penanggulangan bencana berupa Pendidikan Kesehatan tentang Kesiapsiagaan sebagai salah satu upaya yang dilakukan untuk mengantisipasi bencana baik pada masa pra bencana, saat dan pasca terjadinya bencanayang memungkinkan pemerintah, organisasi, masyarakat maupun individu untuk dapat menghadapi bencana yang akanterjadi dengan cara cepat dan tepat. Di sisi lain, peran masyarakat dalammelakukan upaya penanggulangan bencana akan sangat bermanfaat untuk mempersiapkan sebuah rencana tindakan dalam mengurangi dampak masalah kesehatan yang terjadi akibat bencana tanah longsor (Dheny Prasetyo, 2013)

Di desa Nglurup kecamatan sendang sendiri merupakan daerah yang tergolong rawan bencana dan merupakan salah satu daerah yang berpotensi untuk terjadinya bencana tanah longsor (BPBD, 2016). Pelaksanaan pendidikan kesehatan (penyuluhan)tentang kesiapsiagaan, diharapkan masyarakat mampu mempersiapkan dan mengantisipasi masalah kesehatan yang terjadi,baik pada masa pra bencana, saat bencana dan pasca terjadinya bencana. Sehingga nantinya masyarakat diharapkan ikut berperan aktif dalam mengatasi masalah kesehatan dan dampaknya terhadap masalah kesehatan maupun lingkungan akibat bencana tanah longsor tersebut dapat diminimalkan dan di atasi dengan baik.

Berdasarkan permasalahan di atas maka peneliti tertarik untuk mengadakan penelitian dengan merumuskan dalam judul penelitian: "Pengaruh Pendidikan Kesehatan tentang Kesiapsiagaan Masyarakat terhadap Sikap Masyarakat dalam Mengatasi Masalah Kesehatan Akibat Bencana Tanah Longsor di Desa Nglurup, Kec. Sendang, Kabupaten Tulungagung Tahun 2018". Berdasarkan latar belakang di atas, maka rumusan masalah dalam penelitian ini adalah "Apakah ada pengaruh Pendidikan Kesehatan tentang Kesiapsiagaan Masyarakat terhadap Sikap Masyarakat dalam Mengatasi Masalah Kesehatan Akibat Bencana Tanah Longsor?"

\section{METODE}

Desain yang digunakan dalam penelitian ini adalah eksperimen desain pada kelompok penelitian pre eksperimen (one grup pre post test design). Rancangan ini tidak menggunakan kelompok kontrol. Rancangan ini berupayamengungkap hubungan sebab akibat pada kelompok dengan membandingkanhasil pre test dan post test tetapi tanpa melakukan pembanding dengan pengaruh yang dikenakan dalam kelompok lain (Nursalam, 2012).

Pada penelitian ini peneliti menggunakan desain pre eksperimen kelompok yang ada hanya kelompok intervensi yang diberi pendidikan kesehatan tentang kesiapsiagaan dalam mengatasi masalah kesehatan akibat bencana tanah longsor dan akan di teliti sebelum dan sesudah diberi intervensi pada responden dan akan dilihat tingkat kesiapsiagaan dalam mengatasi masalah kesehatan akibat bencana tanah longsor yang berpotensi di wilayah tersebut.

Pada penelitian ini populasinya adalah semua kepala keluarga di Desa Nglurup Kecamatan Sendang Kabupaten Tulungagung yang berjumlah 162 kepala keluarga. Populasi diambil dari kepala keluarga karena mereka merupakan pemimpin dalam anggota keluarga yang sudah mewakili anggota keluarga lain. 
Sampel dalam penelitian ini adalah salah satu anggota keluarga di Desa Nglurup Kecamatan Sendang Kabupaten Tulungagung yang memenuhi kriteria inklusi, didapatkan sejumlah 40 sampel pada penelitian ini.Teknik penentuan sampel yang digunakan adalah quota sampling adalah suatu teknik untuk menentukan sampel dari populasi yang mempunyai ciri-ciri tertentu sampai jumlah kuota yang ditentukan. Instrumen dalam penelitian ini adalah lembar observasi hasil satuan acara pendidikan kesehatan tentang kesiapsiagaan dan kuesioner sikap masyarakat dalam mengatasi masalah kesehatan akibat bencana tanah longsor.
Penelitian ini dilaksanakan pada bulan April 2018 di Balai Desa Nglurup, Kecamatan Sendang, Kabupaten Tulungagung.Analisa data dilakukan dengan uji Wilcoxon Sign Rank Test untuk mengetahui pengaruh variabel independen terhadap variabel dependen. Derajat kemaknaan $\alpha=0,05$ artinya jika uji statistik menunjukkanp $\leq 0,05$ maka ada pengaruh yang signifikan antara variabel independen terhadap variabel dependen.

\section{HASIL}

Adapun hasil penelitian disajikan pada tabel berikut:

Tabel 1.

Sikap responden menghadapi masalah kesehatan akibat bencana tanah longsor sebelum diberikan pendidikan kesehatan tentang kesiapsiagaan masyarakat $(n=40)$

\begin{tabular}{lccc} 
& Sikap & f & $\%$ \\
\hline Negatif & 13 & 32.5 \\
Positif & 27 & 67.5 \\
\hline
\end{tabular}

Tabel 1 memberikan informasi tentang sikap masyarakat sebelum diberikan pendidikan kesehatan menunjukkan bahwa sebagian besar

responden mempunyai sikap positif yaitu sebanyak 27 responden $(67,5 \%)$.

Tabel 2.

Sikap responden menghadapi masalah kesehatan akibat bencana tanah longsor setelah diberikan pendidikan kesehatan tentang kesiapsiagaan masyarakat $(\mathrm{n}=40)$

\begin{tabular}{lccc}
\hline & Sikap & f & $\%$ \\
\hline Negatif & 10 & 25 \\
Positif & 30 & 75
\end{tabular}

Tabel 2 memberikan informasi tentang distribusi frekuensi sikap masyarakat setelah diberikan pendidikan kesehatan, menunjukkan bahwa sebagian besar responden mempunyai sikap positif yaitu sebanyak 30 responden $(75 \%)$.

Tabel 3.

Tabulasi silang sikap responden menghadapi masalah kesehatan akibat bencana tanah longsor sebelum dan sesudah diberikan pendidikan kesehatan tentang kesiapsiagaan masyarakat $(n=40)$

\begin{tabular}{lllccc}
\hline \multicolumn{1}{c}{ Variabel independen } & \multicolumn{2}{c}{ Variabel dependen } & UjiStatistik & P Value & $a$ \\
\hline $\begin{array}{l}\text { Pendidikan kesehatan } \\
\text { tentang kesiapsiagaan }\end{array}$ & $\begin{array}{l}\text { Sikap masyarakat dalam } \\
\text { mengatasi masalah kesehatan } \\
\text { akibat bencana tanah longsor }\end{array}$ & $\begin{array}{c}\text { Wilcoxon } \\
\text { Sign Rank } \\
\text { Test }\end{array}$ & 0,001 & 0,05 \\
\hline
\end{tabular}

Tabel 3 memberikan informasi tentang tabulasi silang sikap masyarakat sebelum dan setelah dilakukan pendidikan kesehatan. Dari tabel tersebut dapat disimpulkan bahwa sebelum dilakuan pendidikan kesehatan, sikap masyarakat memiliki kategori positif sebesar 67,5\% (27 responden). Sedangkan setelah dilakukan pendidikan kesehatan jumlahnya meningkat menjadi $75 \% \quad$ (30 responden).Hasiluji statistik Wilcoxon Sign Range Test tentang pendidikan kesehatan tentang kesiapsiagaan masyarakat terhadap sikap masyarakat dalam mengatasi masalah kesehatan akibat bencana tanah longsor didapat nilai $\rho$ pada kolom asymp.sig (2tailed)sebesar 0,001 lebih kecil dari nlai level of significance $(\alpha)$ yaitu $0,05 \quad(\rho<0,05)$ maka $\mathrm{H}_{1}$ diterima dan $\mathrm{H}_{0}$ ditolak, artinya ada pengaruh pendidikan kesehatan tentang kesiapsiagaan masyarakat terhadap sikap masyarakat dalam mengatasi masalah kesehatan akibat bencana tanah longsor di 
Desa Nglurup, Kecamatan Sendang, Kabupaten Tulungagung Tahun 2018.

\section{PEMBAHASAN}

Sikap masyarakat dalam mengatasi masalah kesehatan akibat bencana tanah longsor sebelum diberikan pendidikan kesehatan tentang kesiapsiagaan masyarakat

Berdasarkan hasil penelitian pada tabel 1 diketahui bahwa dari 40 responden, sebelumdiberikanpendidikan kesehatan tentang kesiapsiagaan masyarakat terhadap sikap masyarakat dalam mengatasi masalah kesehatan akibat bencana tanah longsor, sebagian besar respondenmempunyaisikap positif yaitu sebanyak 27 responden (67,5\%).Menurut Azwar (2012), sikap adalah keteraturan tertentu dalam hal perasaan (afeksi), pemikiran (kognisi), dan predisposisi tindakan (konasi) seseorang terhadap suatu aspek di lingkungan sekitarnya. Sikap merupakan keadaan sikap, bertingkah laku, atau respon yang diberikan atas apa yang terjadi, serta bereaksi dengan cara tertentu yang dipengaruhi oleh keadaan emosional terhadap objek, baik berupa orang, lembaga atau persoalan tertentu yang didalamnya terdapat tiga komponen, yaitu komponen kognitif, komponen afektif, serta komponen tingkah laku.

Berdasarkan fakta dan teori tersebut, peneliti berpendapat bahwa sikap tidak hanya dipengaruhi oleh faktor emosional terhadap objek. Tetapi juga dipengaruhi oleh beberapa faktor lain yang bisa mempengaruhi terbentuknya sikap seseorang. Diantaranya adalah jenis kelamin, usia, pendidikan dan sumber informasi yang diperoleh sebelumnya. Dalam penelitian inimasih ada sebagian dari responden yang memiliki sikap negatif, walaupun sebagian besar dari responden memiliki sikap positif dari sebelum diberikan pendidikan kesehatan.Halini dikarenakan responden memiliki latar belakang yang berbeda. Baik dari segi jenis kelamin, usia, pendidikan dan sumber informasi yang diperoleh sebelumnya.Sehingga hal tersebut dapat mempengaruhi hasil akhir dari pemberian perlakuan terhadap subjek penelitian.
Sikap masyarakat dalam mengatasi masalah kesehatan akibat bencana tanah longsor sesudah diberikan pendidikan kesehatan tentang kesiapsiagaan masyarakat.

Berdasarkan table 2 diketahui bahwa dari 40 responden, sesudah diberikan pendidikan kesehatan tentang kesiapsiagaan masyarakat, sebagian besar responden yaitu sebanyak 30 responden $(75 \%)$ mempunyai sikap positif. Pendidikan kesehatan adalah aplikasi atau penerapan pendidikandalam bidang kesehatan.Secara operasional pendidikan kesehatan adalahsemua kegiatan untuk memberikan dan meningkatkan pengetahuan, sikap,praktik baik individu, kelompok atau masyarakat dalam memelihara dan meningkatkan kesehatan mereka sendiri (Notoatmodjo, 2012).

Menurut WHO (1954) tujuan pendidikan kesehatan adalah untuk mengubah perilaku orang atau masyarakat dari perilaku tidak sehatmenjadi perilaku sehat. Terdapat tiga metode dalam memberikan pendidikan kesehatan yaitu metode individual, metode kelompok dan metode massa. Salah satu metode kelompok adalah ceramah dengan menggunakan media presentasi berupa slide dan juga leaflet. Keberhasilan suatu penyuluhan kesehatan dapat dipengaruhi oleh tiga faktor yaitu faktorpenyuluh, sasaran dan proses penyuluhan.

Berdasarkan fakta dan teori diatas peneliti berpendapat bahwa setelah dilakukan pendidikan kesehatan/ penyuluhan, sebagian besar responden (30 responden) bersikap positif dalam menghadapi masalah kesehatan akibat bencana tanah longsor. Hal tersebut dikarenakan responden telah mendapatkan tambahan informasi yang nantinya akan membentuk sebuah pemahaman dalam pembentukan sikap. Dimana informasi yang diberikan oleh peneliti adalah dengan menggunakan metode kelompok (ceramah) dengan media slide (presentasi) dan leaflet. Melalui hasil penelitian ini peneliti membuktikan bahwa terdapat peningkatan sebanyak 3 responden dalam jumlah sikap positif yang dimiliki oleh responden. 


\section{Sikap masyarakat dalam menghadapi masalah kesehatan akibat bencana tanah longsor sebelum dan sesudah diberikan pendidikan kesehatan tentang kesiapsiagaan masyarakat.}

Berdasarkan tabel 4.1 dan 4.6 didapatkan perubahan sikap positif yang meningkat dari 27 responden $(67.5 \%)$ menjadi 30 responden $(75 \%)$. Sedangkan sikap negatif juga terjadi perubahan dari 13 responden $(32.5 \%)$ menjadi 10 responden (25\%).Berdasarkan hasil analisis komparatif sederhana menggunakan uji statistik Wilcoxon sign rank test (SPSS 16.0 For Windows) dimana tingkat kemaknaan atau $\alpha=0,05$ diperoleh $P_{\text {value }}=0,001$ sehingga $P_{\text {value }}$ $<$ nilai $\alpha$ atau $0,001<0,05$ hal ini dapat disimpulkan bahwa $\mathrm{H}_{0}$ ditolak, $\mathrm{H}_{1}$ diterima yang berarti ada PengaruhPendidikan Kesehatan Tentang Kesiapsiagaan Masyarakat Terhadap Sikap Masyarakat Dalam Mengatasi Masalah Kesehatan Akibat Bencana Tanah Longsor di Desa Nglurup, Kecamatan Sendang Kabupaten Tulungagung.Jadi pada hasil penelitian menunjukkan bahwa ada pengaruh antara pemberian Pendidikan Kesehatan Tentang Kesiapsiagaan Masyarakat terhadap Sikap Masyarakat Dalam Mengatasi Masalah Kesehatan Akibat Bencana Tanah Longsor.

Menurut Azwar S (2011) salah satu faktor yang mempengaruhi sikap yaitu pengalaman pribadi yang dapat menjadi dasar pembentukan sikap apabila pengalaman tersebut meninggalkan kesan yang kuat. Sesuai dengan teori di atas sikap bisa berubah tergantung faktor-faktor yang yang mempengaruhi dari komponen sikap (kognitif, afektif dan konatif) dengan cara pemberian perlakuan, dalam penelitian ini perlakuan untuk mempengaruhi sikap berupa pendidikan kesehatan menggunakan metode kelompok berupa ceramah dengan media slide dan leaflet.

Teori diatas berhubungan dengan teori yang dikemukakan oleh Depkes (2007) bahwa penyuluhan kesehatan adalah pemberian pengetahuan dan kemampuan seseorang melalui teknik belajar atau instruksi dengan tujuan mengubah atau mempengaruhi perilaku manusia secara individu, kelompok maupun masyarakat untuk dapat lebih mandiri dalam mencapai tujuan hidup sehat. hal tersebut sejalan dengan teori yang dikemukakan oleh Azwar (2009) bahwa adanya informasi baru mengenai sesuatu hal memberikan landasan kognitif baru bagi terbentuknya sikap.

Penelitian sejenis pernah dilakukan oleh Kurniawan (2016) dengan judul pengaruh penyuluhan kesehatan tentang donor darah terhadap sikap berdonor darah mahasiswa S1 Keperawatan. Hasil penelitian tersebut adalah ada pengaruh penyuluhan kesehatan tehadap sikap mahasiswa S1 Keperawatan.Teori dan fakta diatas menunjukkan bahwa ada pengaruh Pendidikan Kesehatan tentang kesiapsiagaan masyarakat terhadap sikap masyarakat dalam mengatasi masalah kesehatan akibat bencana tanah longsor di desa Nglurup Kec. Sendang Kab. Tulungagung tahun 2018. Hal ini membuktikan bahwa dengan bertambahnya informasi yang diperoleh melalui pendidikan kesehatan tentang kesiapsiagaan mampu mempengaruhi kepercayaan individu yang mulanya bersikap negatif berubah menjadi positif.

Hal tersebut juga dapat dilihat dari tabel 4.3 terjadi peningkatan jumlah responden yang bersikap positif dan terjadi penurunan responden yang memiliki sikap negatif setelah diberikan penyuluhan. Jadi pendidikan kesehatan merupakan salah satu faktor yang penting dalam pembentukan sikap karena dianggap mampu meletakkan dasar pemahaman, pengertian dan konsep moral dalam diri individu. Dengan adanya Pendidikan kesehatan, diharapkan adanya peningkatan peran masyarakat dalam melakukan upaya penanggulangan bencana dan nantinya bermanfaat untuk mempersiapkan sebuah rencana tindakan dalam mengurangi dampak masalah kesehatan yang terjadi akibat bencana tanah longsor. Sehingga ada perbedaan antara masyarakat yang sudah diberikan Pendidikan kesehatan dengan masyarakat yang tidak mendapat pendidikan kesehatan dalam mengatasi masalah kesehatan akibat bencana tanah longsor. Dan saran untuk peneliti selanjutnya, diharapkan dapat digunakan sebagai referensi dalam melaksanakan penelitian dengan sampel yang lebih banyak, juga dengancara yang berbeda. Di mana dalam penelitian yang telah dilakukan mungkin bisa dibandingkan antara pemberian informasi melalui pendidikan kesehatan dengan pemberian informasi melalui simulasi. Diharapkan dengan metode yang 
berbeda mendapathasil yang lebih baik dari penelitian sebelumnya.

Hasil penelitian setelah dilakukan pendidikan kesehatan tentang kesiapsiagaan terdapat peningkatan sikap masyarakat. Penelitian ini dapat digunakan sebagai salah satu sumber informasi yang diharapkan masyarakat mampu menerapkan kesiapsiagaan bencana yang telah diberikan petugas kesehatan dan dapat mengetahui tindakan-tindakan yang harus dilakukan pada saat terjadi bencana.

\section{SIMPULAN DAN SARAN \\ Simpulan}

Sikap responden sebelum diberikan pendidikan kesehatan tentang kesiapsiagaan, dari 40 responden sebagian besar responden bersikap positif sebanyak 27 responden(67.5\%). Sikap responden sesudah diberikan Pendidikan Kesehatan tentang Kesiapsiagaan, dari 40 responden hampir seluruh dari responden bersikap positif sebanyak 30 responden(75\%). Berdasarkan hasil penelitian dapat disimpulkan bahwa ada pengaruh pendidikan kesehatan tentang kesiapsiagaan terhadap sikap masyarakat dalam mengatasi masalah kesehatan akibat bencana tanah longsor di Desa Nglurup, Kec. Sendang, Kabupaten Tulungagung Tahun 2018". Hal ini dibuktikandariujistatistikWilcoxon Sign Range Test didapatnilai $\mathrm{p}$ padakolomasymp.sig(2tailed)sebesar 0,001 lebih kecil dari nlai level of significance $(\alpha)$ yaitu $0,05(\rho<0,05)$

\section{Saran}

Bagi institusi Pendidikan,dengan dilakukanya penelitian ini diharapkan kepada institusi pendidikan untuk lebih meningkatkan sarana dan prasarana untuk kegiatan penelitian seperti dengan menambah sumber-sumber pengetahuan (referensi) sehingga dapat digunakan sebagai acuan dalam melakukan penelitian berikutnya. Bagi pengembangan ilmu keperawatan, diharapkan dapat lebih mengembangkan ilmu keperawatan dalam bidang kebencanaan dalam sudut pandang keperawatan, dan didukung dengan hasil kajian-kajian yang sesuai dengan bidang keilmuannya. Bagi peneliti selanjutnya, pada penelitian ini diharapkan dapat digunakan sebagai referensi dalam melaksanakan penelitian selanjutnya dengan sampel yang lebih banyak, dengan cara yang berbeda.
Dimana dalam penelitian yang telah dilakukan mungkin bias dibandingkan antara pemberian informasi melalui pendidikan kesehatan dengan pemberian informasi melalui simulasi. Diharapkan dengan metode yang berbeda mendapat hasil yang lebih baik dari penelitian sebelumnya.

\section{DAFTAR PUSTAKA}

Aditya, Dodit (2012). Sosiologi Suatu Pengantar. Bandung: Remaja Karya

Aminudin. (2013). Mitigasi dan Kesiapsiagaan Bencana Alam, Bandung: CV Angkasa

Azwar, S. (2012). Sikap Manusia, Teori dan Pengukurannya. Edisi 2. Yogyakarta :Pustaka Pelajar Offset.

BNPB, 2016 BNPB. (2016). Rekapitulasi Kejadian Bencana Tahun 2016 di Indonesia . http://www.bnpb. go.id

Deny Haryati, dkk. (2013). Pintar Pengelolaan Bencana. Jakarta: Rieneka Cipta

Hidayat, A. Aziz Alimul. (2007). Riset Keperawatan dan Teknik Penulisan Ilmiah. Jakarta: Salemba Medika

Munir, (2012). Multimedia konsep dan aplikasi dalam pendidikan. Bandung : Alfabeta

Notoatmodjo, Soekidjo. (2012). Kesehatan Masyarakat Ilmu \& Seni. Jakarta: Rineka Cipta.

Notoadmojo, Soekidjo. (2012). Promosi Kesehatan Dan Ilmu Perilaku. Jakarta : Rineka Cipta

Nurjanah. (2011). Manajemen Bencana. Bandung: Alfabeta

Nurjanah. (2012). Manajemen Bencana. Bandung: Alfabeta.

Nursalam. 2013.Konsep \& Metodologi Penelitian Ilmu Keperawatan. Edisi Pertama. Jakarta: Salemba Medika.

PMI. (2008). Kesiapsiagaan Bencana Berbasis Masarakat. J1. Gatot Subroto Kav.96 Jakarta Selatan 12970 
Jurnal Keperawatan Jiwa Volume 7 No 1 Hal 71 - 78, Mei 2019

FIKKes Universitas Muhammadiyah Semarang bekerjasama dengan PPNI Jawa Tengah

Ramli, (2010). Kenali tanda-tanda Bencana. Jakarta: SalembaMedika

Sutopo. (2016). Terampil Mengolah Data Kualitatif. Penerbit Prenada Media Group: Jakarta.
Wiarto, Giri. (2017). Tanggap Darurat Bencana Alam. Yogyakarta: Gosyen Publishing 